\title{
NEUROPROTECTIVE AND COGNITIVE ENHANCING EFFECT OF METHANOLIC MORUS ALBA LEAF FRACTION IN U87MG CELL LINES AND EXPERIMENTAL RAT MODEL
}

\author{
ANJALI RAJ ${ }^{1}$, SUMIT DEY ${ }^{2}$, SUBBA RAO VENKATA MADHUNAPANTULA ${ }^{2}$, MANJULA SN ${ }^{1 *}$
}

${ }^{1}$ Department of Pharmacology, Jagadguru Sri Shivarathreeswara College of Pharmacy, JSS Academy of Higher Education and Research, Mysuru, Karnataka, India. ${ }^{2}$ Department of Biochemistry, Center of Excellence in Molecular Biology and Regenerative Medicine, Jagadguru Sri Shivarathreeshwara Medical College, JSS Academy of Higher Education and Research, Mysuru, Karnataka, India. Email: snmanjula@jssuni.edu.in

Received: 08 February 2019, Revised and Accepted: 14 March 2019

\section{ABSTRACT}

Objective: The present study aims to investigate the protective effect of methanol fraction of Morus alba (MEMA) leaves against hydrogen peroxide $\left(\mathrm{H}_{2} \mathrm{O}_{2}\right)$-induced U87MG cell toxicity and aluminum fluoride (ALF)-induced rat toxicity.

Methods: The study was divided into in vitro and in vivo sections. U87MG cell lines were pre-treated with different fractions of MEMA for $20 \mathrm{~h}$ and further tested against $1000 \mathrm{MM}$ of $\mathrm{H}_{2} \mathrm{O}_{2}$. The best fraction from in vitro studies was used to study the protective effects against ALF-induced neurotoxicity. Rats were divided i nto five different groups, and MEMA (200 and $400 \mathrm{mg} / \mathrm{kg} \mathrm{p.o)}$ ) was administered for 14 days to the animals with $\alpha$-tocopherol as the standard drug treatment. Behavioral studies were assessed using Barnes maze. The major biochemical measurements included catalase, superoxide dismutase and glutathione reductase, lipid peroxidation (LPO), and acetylcholinesterase (AchE) levels.

Results: In vitro studies indicated MEMA as a potential candidate followed by AQMA and ethyl acetate. The MEMA fraction was able to ameliorate ALFinduced neurotoxicity in the behavioral assessment. The higher antioxidant content in the fraction decreased the LPO levels from $250 \pm 4.07$ to $115 \pm 3.22$ as well as elevated the levels of most of the endogenous antioxidant enzyme levels. AchE levels were also decreased to $33.89 \pm 0.71$ from $38.94 \pm 0.64$.

Conclusion: Although the results obtained indicate that MEMA could significantly suppress oxidative stress-induced central neuronal damage both in vitro and in vivo, further mechanistic studies are required to delineate its neuroprotective pathway.

Keywords: Morus alba, Methanol fraction of Morus alba, Neuroprotective, Oxidative stress.

(C) 2019 The Authors. Published by Innovare Academic Sciences Pvt Ltd. This is an open access article under the CC BY license (http: //creativecommons. org/licenses/by/4. 0/) DOI: http://dx.doi.org/10.22159/ajpcr.2019.v12i4.32359

\section{INTRODUCTION}

Neurodegenerative diseases pose serious public health concerns with the most prevalent being Alzheimer's disease (AD) followed by Parkinson's disease (PD) [1]. About $5 \%$ of individuals aged 65 or older are affected by $\mathrm{AD}$, whereas $1 \%$ of the individuals aged 60 years are affected by PD $[2,3]$. The evidence further suggests that AD will pose major neurological health concerns in the future [4]. AD accounts for $70 \%$ of cases of dementia, which displays progressive memory loss and cognitive dysfunction $[5,6]$. In 2010, the global cost of dementia was estimated at the United States (US) \$604 billion and it crossed the US \$1 trillion in 2018 [7].

Growing evidence points out oxidative stress and its associated consequences as one of the major risk factors for $\mathrm{AD}$ [8]. Oxidative stress describes a state of imbalance in the production of free radicals and antioxidant defenses $[8,9]$. Oxidative stress is implicated in the vicious circle of amyloid-beta production/accumulation, which is linked with AD development [10]. The primary reactive oxygen species (ROS) scavenging system is associated with oxidative stress, and in the brain, the system constitutes of the antioxidant enzymes such as catalase (CAT), superoxide dismutase (SOD), and glutathione reductase (GSH). Any imbalance to this system could pave ways to amassing of ROS in the system and disrupt the normal poise required to protect the neurons from oxidative injury. Thus, one promising preventive or therapeutic measure for neuroprotection could be to suppress or attenuate the ROS production/accumulation through the exogenous supply of antioxidants and regain the disrupted endogenous oxidative balance [6].

Hydrogen peroxide $\left(\mathrm{H}_{2} \mathrm{O}_{2}\right)$ plays dual roles of ROS by itself and an initiator/precursor for other ROS. Increased utilization of oxygen in the tissues is associated with the higher production of $\mathrm{H}_{2} \mathrm{O}_{2}$ in the brain, which increases the risk of oxidative insult that can lead to apoptosis in various cell types [11]. Upon neurodegeneration, the brain undergoes extensive oxidative stress and rapid biogenic amine metabolism, all of which leads to exacerbation of $\mathrm{H}_{2} \mathrm{O}_{2}$ and other potential toxin accumulations [12]. Likewise, the neurotoxic role of aluminum fluoride (ALF) inducing the formation of the amyloid-beta has gained significance in many debates in the recent past within the western community. The complex is found to cause neurodegeneration mainly through excitotoxicity by activation of protein kinase $\mathrm{C}$ leading to erosion in the animal's cognitive abilities.

Morus alba (MA) or the mulberry plant, whose biological name is MA Linn., is largely being cultivated in the areas of silk harvesting as a food for the silkworms. The medicinal values of the plant, mainly attributed its phenolic content [13], have come into light in a span of a few years. Our inhouse data suggest that the methanol fraction of MA (MEMA) leaves could be used as a protective agent owing to its hydroxyl radical scavenging and anticlastogenic activity [14]. Furthermore, our unpublished in-house data, the leaf extracts have shown protective effects in amyloid-beta and scopolamine-induced animal models by elevating the endogenous antioxidant enzyme levels providing a base to the present work [15]. The present work aims to identify the potent neuroprotective effect of MA leaf fraction by subjecting them to in vitro and in vivo antioxidant tests.

\section{METHODS}

\section{Drugs and chemicals}

Dulbecco's Modified Eagle media (DMEM) and fetal bovine serum (FBS) were purchased from Gibco, Invitrogen. $\mathrm{H}_{2} \mathrm{O}_{2}, \mathrm{ALF}$, sulforhodamine 
(SRB) dye, dichlorodihydrofluorescein diacetate (DCFH-DA), dimethyl sulfoxide (DMSO), acridine orange (AO), and ethidium bromide (EB) were procured from Sigma Aldrich. Thiobarbituric acid and trichloroacetic acid (TCA) were purchased from Hi-Media, Mumbai, India. All solvents (hexane [HEMA], petroleum ether [PEMA], ethyl acetate [ETMA], and methanol) used for extraction were of highperformance liquid chromatography (HPLC) grade procured from Sigma Aldrich.

\section{Plant collection and preparation of fractions}

Fresh leaves were collected from Srirangapatna, Mysuru, India $\left(12.4216^{\circ} \mathrm{N}, 76.6931^{\circ} \mathrm{E}\right)$, and the sample specimen was confirmed by Dr. Naganandini M.N, Department of Pharmacognosy, Jagadguru Sri Shivarathreeshwara College of Pharmacy, Mysuru, India. The leaves were sun dried for 2 days and powdered using a mechanical grinder. Exhaustive Soxhletion method was used for extraction. Coarse powder of the leaves was loaded in the thimble made of Whatman filter paper in the Soxhlet apparatus successively extracted with the solvents in the increasing order of polarity, namely n-HEMA, PEMA, ETMA, MEMA, and water (AQMA). $500 \mathrm{ml}$ of each solvent was used for the extraction. Each of the fraction, i.e., HEMA, PEMA, ETMA, MEMA, and AQMA, respectively, were filtered, concentrated using flash rotary evaporator, dried, and stored in a vacuum desiccator at room temperature till use.

\section{Cell lines}

U87MG glioblastoma cell lines were procured from NCCS, Pune, and maintained in Jagadguru Sri Shivarathreeshwara Medical College. The cell lines were cultured in DMEM supplemented with 10\% FBS and 1\% penicillin at $37^{\circ} \mathrm{C}$ and $5 \% \mathrm{CO}_{2}$.

\section{Animals}

All the experimental and animal handling procedures were approved by the Institutional Animal and Ethics Committee (IAEC) of Jagadguru Sri Shivarathreeshwara College of Pharmacy, Mysuru, India (IAEC approval number $153 / 2014)$. 30 Wistar rats of either sex weighing $250 \pm 50 \mathrm{~g}$ at the start of the experiment were used. The animals were housed in a temperature and light-controlled room $\left(22^{\circ} \mathrm{C}, \mathrm{a} 12 \mathrm{~h}\right.$ dark and $12 \mathrm{~h}$ light cycle), fed, and allowed to drink AQMA ad libitum.

\section{Drug administration}

In in vitro studies, all the fractions were initially dissolved in DMSO and later diluted with the DMEM media. From pilot studies, we found that 10,5 , and $2.5 \mu \mathrm{g} / \mathrm{ml}$ of all the fractions were non-toxic to the cells. Hence, the non-toxic doses were used to perform the cell viability assays, and the best out of these test doses were selected for further assays. $\mathrm{H}_{2} \mathrm{O}_{2}$ in $1000 \mu \mathrm{M}$ at $6 \mathrm{~h}$ was found to exert maximum toxicity $(50 \%)$ from prior cytotoxic dose $(62.5-1000 \mu \mathrm{M})$ and time dependent (2,4 and $6 \mathrm{~h})$ studies.

In in vivo studies, ALF was administered at $600 \mathrm{ppm}$ p.o to the animals from the $7^{\text {th }}$ day of the 14 days experiment design. $\alpha$-Tocopherol $(100 \mathrm{mg} / \mathrm{kg})$ and MEMA (200 and $400 \mathrm{mg} / \mathrm{kg}$ ) were administered orally continuously for 14 days.

\section{In vitro cell culture studies}

\section{Cell viability by SRB assay}

The cytoprotective potential of MA extracts on U87MG glioblastoma cells was assessed using SRB assay [16]. A fixed number of cells ( 5000 cells/well) taken in a volume of $100 \mu \mathrm{L}$ were added to each well of a flat-bottomed 96-well plate and kept in a $\mathrm{CO}_{2}$ incubator until $80 \%$ confluence of the cells for $48 \mathrm{~h}$. The cells were treated with $100 \mu \mathrm{L}$ all the fractions, namely HEMA, PEMA, ETMA, ALMA, and AQMA at concentrations of 10,5 , and $2.5 \mu \mathrm{g} / \mathrm{ml}$ for $20 \mathrm{~h}$ followed by $100 \mu \mathrm{L}$ of $1000 \mu \mathrm{M}$ of $\mathrm{H}_{2} \mathrm{O}_{2}$ for $6 \mathrm{~h}$. At the end of the $26^{\text {th }} \mathrm{h}$, the cells were fixed with $50 \mu \mathrm{l}$ of cold $10 \%(\mathrm{w} / \mathrm{v}$ ) TCA for $1 \mathrm{~h}$, washed with deionized AQMA to remove excess of TCA, dried, and stained with $100 \mu \mathrm{l}$ of $0.4 \%$ (w/v) SRB dye solution for $30 \mathrm{~min}$. The unbound SRB was then removed by washing with $1 \%$ acetic acid solution, and $100 \mu \mathrm{l}$ of $10 \mathrm{mM}$ aqueous tris base buffer was added to dissolve the dye. After thorough shaking, the optical density of the plate was read at $490 \mathrm{~nm}$. The percentage viability was calculated by the formula shown in Equation 1:

PercentageViability $=\left(\frac{A v g-A v g(M B)}{A v g(V C)-A v g(M B)}\right) \times 100$

Equation 1

Where,

Avg - Average of cells in each treatment wells

Avg (MB) - Average of the media blank (only media)

Avg (VC) - Average of cells in vehicle control.

\section{ROS measurement by DCFH-DA}

Fixed number of U87MG cells (5000 cells/well) was seeded in 96well plate. Upon $80 \%$ confluence, cells were treated with $2.5 \mu \mathrm{g} / \mathrm{ml}$ of MEMA. Briefly, the cells were pre-treated with $2.5 \mu \mathrm{g} / \mathrm{ml}$ of methanol extract for $20 \mathrm{~h}$. The media was removed and washed once with PBS and incubated with DCFH-DA solution $(20 \mu \mathrm{M} /$ well $)$ for $30 \mathrm{~min}$. The cells were then treated with $1000 \mu \mathrm{M}$ of $\mathrm{H}_{2} \mathrm{O}_{2}$ for $6 \mathrm{~h}$. Finally, at the end of the $6^{\text {th }} \mathrm{h}$, the fluorescence intensity (FI) of DCF was measured in a microplate reader with an excitation wavelength of $485 \mathrm{~nm}$ and an emission wavelength of $535 \mathrm{~nm}$ [17].

\section{Fluorescent imaging by dual staining}

Dual staining with EB and AO was performed [18]. Fixed number of U87MG cells (5000 cells) were treated with MEMA $(2.5 \mu \mathrm{g} / \mathrm{ml})$ and $1000 \mu \mathrm{M}$ of $\mathrm{H}_{2} \mathrm{O}_{2}$. Upon completion of the treatment, the cells were trypsinized and suspended in PBS $(25 \mu \mathrm{L})$ from each group and were mixed with $1 \mu \mathrm{L} \mathrm{AO/EB}$ for 15 min just before microscopic evaluation. A thin smear of stained cells was prepared on microscopic slides. Images were captured using a fluorescent microscope.

\section{In vivo neuroprotective study \\ Experimental}

The rats were divided into five groups of six each: (1) Control group received saline treatment $(0.9 \% \mathrm{NaCl}),(2)$ standard group received $\alpha$-tocopherol pre-treatment followed by ALF ( $600 \mathrm{ppm})$ treatment for 7 days, (3) ALF (600 ppm) alone-treated group, (4) MEMA leaves pretreated group received ALF treatment for 7 days (MEMA1 [200 mg/kg] + ALF), and (5) MEMA leaves (MEMA2 [400 mg/kg] + ALF) pre-treated group received ALF treatment for 7 days. Control and ALF alone-treated groups were caged in the same conditions but in the absence of the treatment.

\section{Spatial learning and memory-Barnes maze task}

Spatial learning and memory of the experimental animals were tested by the Barnes maze $[15,19]$. The apparatus consisted of a clear circular platform $(13 \mathrm{~cm} \times 29 \mathrm{~cm} \times 14 \mathrm{~cm})$ with 12 equally spaced holes $(10 \mathrm{~cm}$ diameter) located $2 \mathrm{~cm}$ from the border. The circular platform was virtually divided into four zones (including the target quadrant with the escape hole and the opposite quadrant). Each trial began by placing the animal in a black cylinder at the center of the platform that was removed after $10 \mathrm{~s}$, allowing mice to freely explore the apparatus. The spatial acquisition was organized in four training sessions (day 1 and 2-2 trails/day). Rats that failed to find the target box within 3 min were gently guided to its location, and for those rats, $180 \mathrm{~s}$ were recorded as the escape latency. All animals remained in the target box for $60 \mathrm{~s}$ after entering.

The following parameters were scored during all training trials: Latency to escape and a total number of errors. Escape latency was defined as the time taken by animals to completely enter the target box (all four paws out of the platform). Total errors were defined as the total number of holes visited during the trial other than the target hole. A hole was considered visited when rats tilted their head over it (nose poke) or introduced their paws into the hole.

On day 14 , reference short-term memory was evaluated by a probe trial (90 s) during which the target box was removed. The latency to find 
the target hole (without box) was determined. Furthermore, rats were once again submitted to the acquisition trial in the same conditions to evaluate long-term retention. No training occurred between days 7 and 14.

Estimation of the endogenous antioxidant enzymes and lipid peroxidation (LPO)

The rats were decapitated under anesthesia (ketamine) [20]. The skull was cut open, and the brain was exposed from its dorsal side. The whole brain was quickly removed and cleaned with chilled $0.1 \mathrm{M}$ sodium phosphate buffer ( $\mathrm{pH} 7.4)$. A 10\% (w/v) homogenate of brain samples (0.1 M sodium phosphate buffer, $\mathrm{pH} 7.4)$ were prepared using homogenizer and then centrifuged at $4000 \mathrm{rpm}$ for $10 \mathrm{~min}$ at $4^{\circ} \mathrm{C}$. The supernatant homogenate was used to measure, total protein content (Spinreact), and the activities of CAT, SOD, GSH, and LPO based on the standard methods [21-24].

\section{Determination of acetylcholinesterase (AchE) activity}

The AchE enzymatic assay was determined by spectrophotometric method [25]. The reaction mixture (2 $\mathrm{ml}$ final volume) contained $100 \mathrm{mM}$ potassium phosphate buffer, $\mathrm{pH} 7.5$ and $1 \mathrm{mM}$ $5,5^{\prime}$-dithiobisnitrobenzoic acid. The method is based on the formation of the yellow anion, 5,5'-dithio-bis-acidnitrobenzoic, measured by absorbance at $412 \mathrm{~nm}$ during 2-min incubation at $25^{\circ} \mathrm{C}$. The reaction was initiated by adding $0.8 \mathrm{mM}$ acetylthiocholine iodide. All samples were run in triplicate, and change in absorbance per minute is recorded in the kinetic mode of a spectrophotometer for $3 \mathrm{~min}$ at $412 \mathrm{~nm}$.

\section{Statistical analysis}

Data are shown as means \pm standard error of the mean (SEM). Statistical analysis was performed using Prism 5 (GraphPad). One-way and twoway repeated measures ANOVA followed by Tukey's and Bonferroni post hoc analysis were used for probe day and training trials data, respectively. The level of significance was set at $\mathrm{p}<0.05$

\section{RESULTS}

Cytoprotective activity of MA fractions against $\mathrm{H}_{2} \mathrm{O}_{2}$-induced cytotoxicity

U87MG cells were pre-treated with 10,5 , and $2.5 \mu \mathrm{g} / \mathrm{ml}$ of all the fractions for $20 \mathrm{~h}$, and cytotoxicity was induced using $\mathrm{H}_{2} \mathrm{O}_{2}$ for $6 \mathrm{~h}$. All fractions except PEMA reduced the cytotoxicity induced by $\mathrm{H}_{2} \mathrm{O}_{2}$, but pre-treatment with MEMA at $2.5 \mu \mathrm{g} / \mathrm{ml}$ significantly increased the cell viability compared to $\mathrm{H}_{2} \mathrm{O}_{2}$-treated cells and as well as the control (Table 1)

\section{ROS generation by dichlorodihydrofluorescein diacetate}

Cells were pre-treated with MEMA for $20 \mathrm{~h}$ and further treated with $\mathrm{H}_{2} \mathrm{O}_{2}$ for $6 \mathrm{~h}$. The conversion of non-fluorescent DCFH-DA to fluorescent DCF in the presence of ROS was fluorometrically detected. MEMA $(2.5 \mu \mathrm{g} / \mathrm{ml})$ being the most effective dose was used to determine the ROS scavenging activity for providing evidence to the prior in vitro antioxidant results as well as a base to the dose selection for in vivo studies. MEMA $(2.5 \mu \mathrm{g} / \mathrm{ml})$ could scavenge the $\mathrm{H}_{2} \mathrm{O}_{2}$ generated ROS compared to the $\mathrm{H}_{2} \mathrm{O}_{2}$-treated group but could not bring back to the normal levels (Table 2).

\section{Fluorescent imagining by dual staining}

Fluorescent staining of U87MG cells was performed using AO/EB for qualitative analysis. MEMA pre-treated cells showed significant cell viability (green color) compared to the $\mathrm{H}_{2} \mathrm{O}_{2}$ treatment, whereas $\mathrm{H}_{2} \mathrm{O}_{2}$ treated cells showed significant cell death compared to control. The images were captured using fluorescent microscope (Olympus) (Fig. 1).

Effect of MEMA on spatial learning and memory by Barnes maze The ALF-treated group significantly increased mean escape latencies throughout the training days when compared with normal. $\alpha$-tocopherol significantly reduced the escape latencies and number of error compared to ALF-treated group and significantly increased
Table 1: Effect of Morus alba leaf fractions on $\mathrm{H}_{2} \mathrm{O}_{2}$-induced cell death in U87MG cell lines $(n=3)$

\begin{tabular}{lll}
\hline Group & Treatment & \% viability \\
\hline 1 & Control & $87.89 \pm 0.97$ \\
2 & $\mathrm{H}_{2} \mathrm{O}_{2}$ & $49 \pm 2.13^{\mathrm{a}}$ \\
3 & HEMA $(10 \mu \mathrm{g} / \mathrm{ml})$ & $63.21 \pm 3.24^{\mathrm{b}}$ \\
4 & HEMA $(5 \mu \mathrm{g} / \mathrm{ml})$ & $59.21 \pm 5.81^{\mathrm{a}, \mathrm{b}}$ \\
5 & HEMA $(2.5 \mu \mathrm{m} / \mathrm{ml})$ & $50.30 \pm 6.94^{\mathrm{a}}$ \\
6 & PEMA $(10 \mu \mathrm{g} / \mathrm{ml})$ & $57.13 \pm 4.7^{\mathrm{a}}$, \\
7 & PEMA $(5 \mu \mathrm{g} / \mathrm{ml})$ & $50.12 \pm 3.99^{\mathrm{a}}$ \\
8 & PEMA $(2.5 \mu \mathrm{g} / \mathrm{ml})$ & $48.98 \pm 4.5^{\mathrm{a}}$ \\
9 & ETMA $(10 \mu \mathrm{g} / \mathrm{ml})$ & $77.01 \pm 7.12^{\mathrm{b}}$ \\
10 & ETMA $(5 \mu \mathrm{g} / \mathrm{ml})$ & $71.31 \pm 6.87^{\mathrm{b}}$ \\
11 & ETMA $(2.5 \mu \mathrm{g} / \mathrm{ml})$ & $80.42 \pm 4.94^{\mathrm{b}}$ \\
12 & MEMA $(10 \mu \mathrm{g} / \mathrm{ml})$ & $88.17 \pm 5.92^{\mathrm{b}}$ \\
13 & MEMA $(5 \mu \mathrm{g} / \mathrm{ml})$ & $91.53 \pm 3.36^{\mathrm{b}}$ \\
14 & MEMA $(2.5 \mu \mathrm{g} / \mathrm{ml})$ & $97.04 \pm 5.55^{\mathrm{b}}$ \\
15 & AQMA $(10 \mu \mathrm{g} / \mathrm{ml})$ & $79.17 \pm 3.73^{\mathrm{b}}$ \\
16 & AQMA $(5 \mu \mathrm{g} / \mathrm{ml})$ & $83.87 \pm 6.82^{\mathrm{b}}$ \\
17 & AQMA $(2.5 \mu \mathrm{g} / \mathrm{ml})$ & $86.96 \pm 5.91^{\mathrm{b}}$ \\
\hline
\end{tabular}

Data were analyzed by one-way ANOVA followed by post hoc Tukey's multiple comparison test. ${ }^{\mathrm{a}} \mathrm{p}<0.05$ compared to control blank and ${ }^{\mathrm{b}} \mathrm{p}<0.05$ compared to $\mathrm{H}_{2} \mathrm{O}_{2}$. $\mathrm{H}_{2} \mathrm{O}_{2}$ : Hydrogen peroxide, HEMA: Hexane, PEMA: Petroleum ether, ETMA: Ethyl acetate, MEMA: Methanol fraction of Morus alba

Table 2: Effect of MEMA on $\mathrm{H}_{2} \mathrm{O}_{2}$-induced ROS generation in U87MG cell lines $(n=3)$

\begin{tabular}{ll}
\hline Group & $\begin{array}{l}\text { Fluorescence } \\
\text { intensity (mean) }\end{array}$ \\
\hline Control & 109.25 \\
$\mathrm{H}_{2} \mathrm{O}_{2}$ & $159^{\mathrm{a}}$ \\
MEMA $(2.5 \mu \mathrm{g} / \mathrm{ml})$ & $111.38^{\mathrm{b}}$ \\
MEMA $(2.5 \mu \mathrm{g} / \mathrm{ml})+\mathrm{H}_{2} \mathrm{O}_{2}$ & $129.25^{\mathrm{a}, \mathrm{b}}$ \\
\hline
\end{tabular}

Data were analyzed by one-way ANOVA followed by post hoc Tukey's multiple comparison test. ${ }^{\mathrm{a}} \mathrm{p}<0.05$ compared to control blank and ${ }^{\mathrm{b}} \mathrm{p}<0.05$ compared to $\mathrm{H}_{2} \mathrm{O}_{2} \cdot \mathrm{H}_{2} \mathrm{O}_{2}$ : Hydrogen peroxide, ROS: Reactive oxygen species, MEMA: Methanol fraction of Morus alba

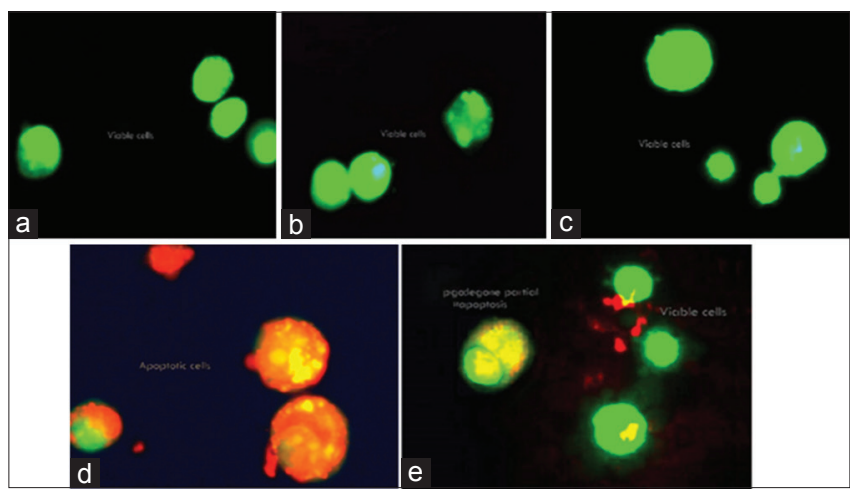

Fig. 1: Dual-stained images of treated and control cells under fluorescent microscope. Figures represent the different treated cells and the cell blank after dual staining viewed under fluorescent microscope. (a) Cell blank, (b) vehicle control (dimethyl sulfoxide), (c) methanol fraction of Morus alba (MEMA) $(2.5 \mu \mathrm{g} / \mathrm{ml}),(\mathrm{d})$ hydrogen peroxide $\left(\mathrm{H}_{2} \mathrm{O}_{2}\right)(1000 \mu \mathrm{M}$ for $6 \mathrm{~h})$, and (e) MEMA $(2.5 \mu \mathrm{g} / \mathrm{ml}$ for $20 \mathrm{~h})+\mathrm{H}_{2} \mathrm{O}_{2}(1000 \mu \mathrm{M}$ for $6 \mathrm{~h})$

the time spent in escape quadrant. MEMA also at both the doses significantly succeeded in shortening the escape latencies prolonged by ALF treatment as well as number of errors made. In the probe trial, MEMA1 (Table 3) (200 mg/kg) pre-treated group significantly increased the time spent in the escape quadrant as compared to the standard treatment (Fig. 2). 


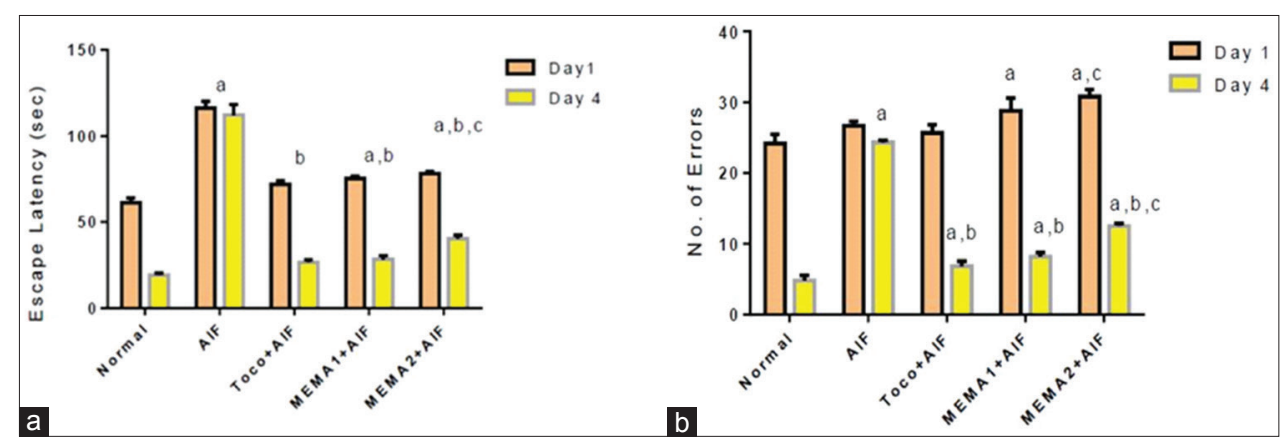

Fig. 2: Effect of methanol fraction of Morus alba (MEMA) on spatial learning and memory by Barnes maze. (a) Effect of MEMA on escape latencies in Barnes maze and (b) effect of MEMA on total number of errors made in Barnes maze. All values were expressed as mean \pm standard error of the mean, $n=6$. Data were analyzed by two-way ANOVA followed by post hoc Bonferroni's multiple comparison test.

\section{Effect of MEMA on endogenous antioxidant enzymes}

Reports indicate that the endogenous antioxidant enzyme levels are found least in the brain compared to other organs [26]. Hence, it is important to check the levels of these enzymes pre- and post-treatment to confirm the antioxidant efficacy of the fraction. After ALF treatment, rat brains showed a marked decrease in SOD, GSH, and CAT levels when compared with normal. $\alpha$-tocopherol (100 mg/kg i.p) significantly increased the decline in ALF-induced brain endogenous enzymes while the treatment with MEMA at both doses $(200$ and $400 \mathrm{mg} / \mathrm{kg}$ ) significantly reversed the dropped brain enzymes level (Table 4).

\section{Effect of MEMA on brain AchE activity}

Acetylcholine is considered to be very important in proper brain functions especially memory and related cognitive domains. AchE enzyme causes breakdown of Ach leading to its loss of activity. The direct levels of Ach measurement are a bit tedious due to the highly sensitive and unstable nature of the neurotransmitter, and hence, the levels of AchE are estimated to indirectly give a measurement of Ach levels in the brain [27]. AchE activity in normal animals was found to be $27.72 \pm 1.77 \mu \mathrm{M} / \mathrm{min} / \mathrm{mg}$ protein. AchE activity was significantly increased in animals treated with ALF $(38.94 \pm 0.64)$ when compared with normal. MEMA at 200 and $400 \mathrm{mg} / \mathrm{kg}$ and standard significantly reversed the increase in AchE activity treated by ALF (Table 5).

\section{Effect of MEMA on LPO}

The LPO levels are one of the most important markers of oxidative stress. Lipids when reacting with free radicals undergo peroxidation to form lipid peroxides indirectly indicating the free radical density [28]. The MEMA1 treatment not only significantly reduced the malondialdehyde (MDA) formed due to ALF-induced stress compared to the control group but also the values were analogous the standard treatment (Table 6).

\section{DISCUSSION}

Ample evidence from preclinical and clinical studies prove the role of oxidative stress in the pathogenesis of neurodegenerative diseases. The oxygen-free radicals are found to play an important role in the decline of the health status of the elderly [29]. Finding novel and effective treatment agents that modify the disease course through neuroprotective therapy either by slowing down disease progression or promoting the genesis of new neurons are an unmet clinical need [30]. Exogenous administration of antioxidants to scavenge the generated free radicals and strengthen the endogenous antioxidant enzymes is one such treatment strategy. Plants and its products are splendid sources of antioxidants and hence have been used for its therapeutic benefits and to increase the effectiveness of treatment. The MEMA leaves are found to exert beneficial effects comparable to Ginkgo biloba for AD in addition to its anti-A $\beta$ aggregation effect in primary hippocampal cell cultures at a concentration of $30 \mathrm{mg} / \mathrm{ml}$ [31]. With this aim, the present study was selected to explore the possible neuroprotective activity of leaves of MA against $\mathrm{H}_{2} \mathrm{O}_{2}$ cytotoxicity and ALF-induced neurotoxicity.
Table 3: Effect of MEMA on probe trial in Barnes maze ( $n=6)$

\begin{tabular}{ll}
\hline Groups & $\begin{array}{l}\text { Latency to find target } \\
\text { hole (s) }\end{array}$ \\
\hline Normal & $71.17 \pm 4.19$ \\
ALF & $20.1 \pm 1.35^{\mathrm{a}}$ \\
$\alpha$-tocopherol+ALF & $67.67 \pm 2.60^{\mathrm{b}}$ \\
MEMA1+ALF & $63 \pm 2.19^{\mathrm{b}}$ \\
MEMA2+ALF & $50.17 \pm 2.32^{\mathrm{a}, \mathrm{b}, \mathrm{c}}$ \\
\hline
\end{tabular}

Data were analyzed by one-way ANOVA followed by post hoc Tukey's multiple comparison test where ${ }^{\mathrm{a}} \mathrm{p}<0.05$ compared to normal, ${ }^{\mathrm{b}} \mathrm{p}<0.05$ compared to $\mathrm{ALF},{ }^{\mathrm{c}} \mathrm{p}<0.05$ compared to standard. MEMA: Methanol fraction of Morus alba, ALF: Aluminum fluoride

As mentioned earlier, $\mathrm{H}_{2} \mathrm{O}_{2}$ is a generator as well as a propagator of ROS in the living system. An elevation in $\mathrm{H}_{2} \mathrm{O}_{2}$ levels correlates with the toxic consequences of $\mathrm{AD}$ and $\mathrm{A} \beta$, and reports suggest that $\mathrm{A} \beta$ increases $\mathrm{H}_{2} \mathrm{O}_{2}$ accumulation in the cells indicating a "second messenger" role of $\mathrm{H}_{2} \mathrm{O}_{2}$ which induces apoptosis [32]. In-vitro studies have also demonstrated morphological and biochemical similarities between amyloid beta and $\mathrm{H}_{2} \mathrm{O}_{2}$ induced neurotoxicities [33]. Hence, we presumed in our study that levels of cytoprotection extended by the fractions against $\mathrm{H}_{2} \mathrm{O}_{2}$-induced toxicity could also provide an indirect mechanism for their neuroprotective activity against $\mathrm{A} \beta$-induced toxicity.

Fractions were subjected to in vitro neuroprotective assay on the human glioblastoma cell lines (U87MG) against $\mathrm{H}_{2} \mathrm{O}_{2}$-induced cytotoxicity. The U87MG cells pre-treated with all the fractions followed by $\mathrm{H}_{2} \mathrm{O}_{2}(1000 \mathrm{lo})$ treatment $6 \mathrm{~h}$ were found to resist death in most of the groups except for PEMA but actually increased the number of cells in the MEMA group possibly due to its higher antioxidants, especially phenolic content [14]. Due to the significant protective effect of the methanol fraction at $2.5 \mu \mathrm{g} / \mathrm{ml}$, it was selected for further studies. As discussed earlier, hydroxyl radicals are identified to be one of the major contributors to aging and most of the chronic diseases. In addition, direct exposure of $\mathrm{H}_{2} \mathrm{O}_{2}$ has been reported to block glutathione biosynthesis and induce oxidative stress, resulting in apoptotic cell death [34]. Our previous in-house data indicated a prominent hydroxyl radical scavenging activity for the MEMA fraction. Hence, there was a requirement of reproducibility for the same effect in a living system for which FI produced on conversion of DCFH-DA to DCF in the presence of ROS (which also includes $\mathrm{OH}$ radicals) was estimated. MEMA $2.5 \mu \mathrm{g} /$ $\mathrm{ml}$ readily scavenged $\mathrm{H}_{2} \mathrm{O}_{2}$ generated ROS and markedly decreased the FI compared to the $\mathrm{H}_{2} \mathrm{O}_{2}$. Further, fluorescent imaging was performed to qualitatively confirm the protective mechanism of MEMA at $2.5 \mu \mathrm{g} /$ $\mathrm{ml}$. The results supported the protective data obtained from the above assays. The significant antioxidant ability of MEMA might delay the occurrence of apoptosis or prevent it altogether.

From numerous neurotoxins, ALF particularly stands out due to the combination of two potent neurotoxins: ALF. Being individually toxic, 
Table 4: Effect of MEMA on endogenous antioxidant enzymes (catalase, SOD, and GSH) (n=6)

\begin{tabular}{llll}
\hline Group & Catalase $(\mu /$ mg protein $)$ & SOD $(\boldsymbol{\mu} / \mathbf{m g}$ protein) & GSH (Mmole/g/tissue) \\
\hline Normal & $7.32 \pm 2.21$ & $10.96 \pm 3.21$ & $21.4 \pm 2.57$ \\
ALF & $1.84 \pm 3.51^{\mathrm{a}}$ & $0.992 \pm 5.41^{\mathrm{a}}$ & $8.46 \pm 4.11^{\mathrm{a}}$ \\
$\alpha$-tocopherol+ALF & $5.82 \pm 5.27^{\mathrm{a}, \mathrm{b}}$ & $0.93 \pm 4.2^{\mathrm{b}}$ & $20.21 \pm 3.77^{\mathrm{b}}$ \\
MEMA1+ALF & $4.78 \pm 3.34^{\mathrm{a}, \mathrm{b}}$ & $7.98 \pm 2.03^{\mathrm{a}, \mathrm{b}}$ & $18.78 \pm 2.57^{\mathrm{a}, \mathrm{b}}$ \\
MEMA2+ALF & $3.73 \pm 3.34^{\mathrm{a}, \mathrm{b}, \mathrm{c}}$ & $6.12 \pm 2.30^{\mathrm{a}, \mathrm{b}}$ & $15.11 \pm 4.47^{\mathrm{a}, \mathrm{b}, \mathrm{c}}$ \\
\hline
\end{tabular}

Data are expressed as mean \pm SEM. Data were analyzed by one-way ANOVA followed by post hoc Tukey's multiple comparison test. In Table 3 , ${ }^{\text {a }}<0.05$ compared to normal, ${ }^{b} \mathrm{p}<0.05$ compared to ALF, and ${ }^{\mathrm{c}} \mathrm{p}<0.05$ compared to standard. SEM: Standard error of the mean, SOD: Superoxide dismutase, GSH: Glutathione reductase,

MEMA: Methanol fraction of Morus alba

Table 5: Effect of MEMA on AchE levels $(n=6)$

\begin{tabular}{ll}
\hline Group & AchE activity $(\mu \mathrm{M} / \mathbf{m i n} / \mathbf{m g})$, Mean \pm SEM \\
\hline Normal & $27.72 \pm 1.77$ \\
ALF & $38.94 \pm 0.64^{\mathrm{a}}$ \\
$\alpha$-tocopherol+ALF & $32.56 \pm 0.56^{\mathrm{a}, \mathrm{b}}$ \\
MEMA1+ALF & $33.18 \pm 0.60^{\mathrm{a}, \mathrm{b}}$ \\
MEMA2+ALF & $33.89 \pm 0.71^{\mathrm{a}, \mathrm{b}}$ \\
\hline
\end{tabular}

Data were analyzed by one-way ANOVA followed by post hoc Tukey's multiple comparison test. In Table $4,{ }^{a} \mathrm{p}<0.05$ compared to normal while ${ }^{\mathrm{b}} \mathrm{p}<0.05$ compared to ALF. ALF: Aluminum fluoride, MEMA: Methanol fraction of Morus alba, AchE: Acetylcholinesterase

Table 6: Effect of MEMA on lipid peroxidation $(n=6)$

\begin{tabular}{ll}
\hline Group & $\begin{array}{l}\text { Lipid peroxidation } \\
\text { (nmol TBARS/min/mg tissue) }\end{array}$ \\
\hline Normal & $88 \pm 3.06$ \\
ALF & $250 \pm 4.07^{\mathrm{a}}$ \\
$\alpha$-tocopherol+ALF & $104 \pm 2.14^{\mathrm{a}, \mathrm{b}}$ \\
MEMA1+ALF & $115 \pm 3.22^{\mathrm{a}, \mathrm{b}}$ \\
MEMA2+ALF & $130 \pm 2.60^{\mathrm{a}, \mathrm{b}, \mathrm{c}}$ \\
\hline
\end{tabular}

Data were analyzed by one-way ANOVA followed by post hoc Tukey's multiple comparison test. In Table 5 , ${ }^{a} \mathrm{p}<0.05$ compared to normal while ${ }^{\mathrm{b}} \mathrm{p}<0.05$ compared to ALF. ALF: Aluminum fluoride, MEMA: Methanol fraction of Morus alba, TBARS: Thiobarbituric acid reactive substances

their combination is found to be highly neuronal degrading since the complex interferes with most of all the neurochemical functions including impairing glutamate transporters and microglial activation all of which finally leading to excitotoxicity. The toxin is found to significantly increase the ROS/reactive nitrogen species and LPO products leading to mitochondrial dysfunction ultimately facilitating the accumulation of neurodegenerative products such as $A \beta$ and tau. $\mathrm{Al}$, being an abundant metal, and fluoride, a component of drinking water, possess many chances in our everyday lives to react and form the deadly "AlF duo" $[12,35]$. Hence, the model is important to be studied to predict its consequences likely to be posed to human society.

Previous investigations and in vitro studies carried out indicate methanol fraction to be more active compared to other fractions. Hence, the MEMA fractions at doses of 200 and $400 \mathrm{mg} / \mathrm{kg}$ were chosen for in vivo studies directed against ALF-induced neurotoxicity. The escape latency and number of errors were assessed using Barnes maze. MEMA at 200 and $400 \mathrm{mg} / \mathrm{kg}$ dose substantially shortened the escape latencies prolonged by ALF and also reduced the total number of errors made by the animals while acquisition. MEMA1 $(200 \mathrm{mg} / \mathrm{kg})$ had an effect comparable to the standard. The cognitive enhancement could be due to PDE4 inhibition by Moracin present in the leaves leading to the increased cyclic adenosine monophosphate levels in the hippocampus indicated in memory enhancement [36].

The evaluation of biochemical parameters was performed to support the data obtained from the behavioral studies. In comparison with control, the fraction at both the doses considerably decreased the AchE activity, but MEMA1 showed similar efficacy as that of the $\alpha$-tocopherol group in the reduction MDA levels. The decreased AchE activity may be attributed to the antiserotonergic effect of MEMA fraction which assists in the enhanced release of Ach from the cortical area [37]. Both the doses of MEMA considerably increased the levels of CAT, SOD, and GSH, when compared to AlF treated group with MEMA1 exhibiting a slightly increased activity, correlating to our previous antioxidant activity reports.

\section{CONCLUSION}

The present study indicated that pre-exposure to MEMA leaves could effectively restore antioxidant brain status both in vitro and in vivo and may confer neuroprotection due to the alleviation of oxidative damage induced by two different toxins. Therefore, MEMA could be a potential candidate for the further preclinical study aimed at the moderation of dementia symptoms in neurodegenerative diseases.

\section{ACKNOWLEDGMENT}

The authors are thankful to Principal, JSS College of Pharmacy, Mysuru, and Principal, JSS Medical College, JSS Academy of Higher Education and Research, Mysuru, for providing necessary infrastructure in completing the project.

\section{AUTHOR'S CONTRIBUTION}

Miss Anjali Raj performed the in vivo studies while Mr. Sumit Dey performed the in vitro studies at JSS Medical College. Dr. Subbarao was instrumental in formulating and guiding the in vitro work while Dr. Manjula supervised the entire work. All the authors have contributed equally in reviewing the manuscript.

\section{CONFLICT OF INTEREST}

The authors declare no conflicts of interest.

\section{REFERENCES}

1. Erkkinen MG, Kim MO, Geschwind MD. Clinical neurology and epidemiology of the major neurodegenerative diseases. Cold Spring Harb Perspect Biol 2018;10:33118.

2. Ghezzi L, Scarpini E, Galimberti D. Disease-modifying drugs in Alzheimer's disease. Drug Des Devel Ther 2013;7:1471-8.

3. Chiu PY, Tsai CT, Chen PK, Chen WJ, Lai TJ. Neuropsychiatric symptoms in Parkinson's disease dementia are more similar to Alzheimer's disease than dementia with lewy bodies: A Case-control study. PLoS One 2016;11:e0153989.

4. Sejvar JJ. Global burden of neurological disease: What's in a name? Lancet Neurol 2017;16:858-9.

5. Winblad B, Amouyel P, Andrieu S, Ballard C, Brayne C, Brodaty H, et al. Defeating Alzheimer's disease and other dementias: A priority for European science and society. Lancet Neurol 2016;15:455-532.

6. Purushothuman S. Oxidative stress in neurodegenerative conditions and the protective potential of a natural antioxidant, dietary saffron. Oxid Antioxid Med Sci 2015;4:112-3.

7. Wimo A, Guerchet M, Ali GC, Wu YT, Prina AM, Winblad B, et al. The worldwide costs of dementia 2015 and comparisons with 2010. Alzheimers Dement 2017;13:1-7.

8. Mansour SZ, Moustafa EM, Hassan AA, Thabet NM. Protective role of krill oil against estrogen deficiency induced neurodegeneration in ovariectomized mice. Indian J Exp Biol 2017;55:279-80. 
9. Betteridge DJ. What is oxidative stress? Metabolism 2000;49:3-8.

10. Chonpathompikunlert P, Han J, Toh K, Isoda H, Nagasaki Y. TEMPOL protects human neuroblastoma SH-SY5Y cells against $\beta$-amyloidinduced cell toxicity. Eur J Pharmacol 2011;650:544-9.

11. Milton NG. Role of hydrogen peroxide in the aetiology of Alzheimer's disease: Implications for treatment. Drugs Aging 2004;21:81-100.

12. Singh JC, Alagarsamy V, Parthiban P, Selvakumar P, Reddy YN. Neuroprotective potential of ethanolic extract of Pseudarthria viscida (L) Wight and arn against beta-amyloid (25-35)-induced amnesia in mice. Indian J Biochem Biophys 2011;48:197-201.

13. Mclachlan D. Aluminum and Alzheimer's disease. Alzheimer Dis Assoc Disord 1987;1:209-10.

14. Imran M, Khan H, Shah M, Khan R, Khan F. Chemical composition and antioxidant activity of certain Morus species. J Zhejiang Univ Sci B 2010;11:973-80.

15. Raj A, Mruthunjaya K, Madhunapantula S, Manjula S. Comparative assessment of the anti-oxidant and anti-clastogenic activity of Morus alba leaves. Free Radic Antioxid 2016;7:123-7.

16. Kumar VS. Studies to Assess the Effect of Morus alba Against Scopolamine Induced Memory Impairment and Amyloid $\beta$-Peptide1-40 Induced Neurotoxicity. Master of Pharmacy Thesis. Mysore: Jagadguru Sri Shivarathreeshwara University; 2014.

17. Thakor V, Poddar M, Dey S, Manjula S, Madhunapantula S, Pawara R, et al. Exploring the anti-breast cancer potential of flavonoid analogs. RSC Adv 2016;6:79166-79.

18. Armstrong JS, Steinauer KK, Hornung B, Irish JM, Lecane P, Birrell GW, et al. Role of glutathione depletion and reactive oxygen species generation in apoptotic signaling in a human B lymphoma cell line. Cell Death Differ 2002;9:252-63.

19. Liu K, Liu PC, Liu R, Wu X. Dual AO/EB staining to detect apoptosis in osteosarcoma cells compared with flow cytometry. Med Sci Monit Basic Res 2015;21:15-20.

20. Darcet F, Mendez-David I, Tritschler L, Gardier AM, Guilloux JP, David DJ, et al. Learning and memory impairments in a neuroendocrine mouse model of anxiety/depression. Front Behav Neurosci 2014;8:136.

21. Khan RA, Khan MR, Sahreen S. Brain antioxidant markers, cognitive performance and acetylcholinesterase activity of rats: Efficiency of Sonchus asper. Behav Brain Funct 2012;8:21.

22. Sinha AK. Colorimetric assay of catalase. Anal Biochem 1972;47: 389-94.

23. Kinattingal N, Manjula SN, Mruthunjaya K, Mahalakshmi AM. Cardioprotective effect of Tamarindus indica linn against isoproterenol induced myocardial infarction in rats. Int $\mathrm{J}$ Pharm Pharm Sci 2016;8:254-60.

24. Babu SM, Swain S, Renuka K. Neuroprotective activity of fractional flower extracts of Mirabilis jalapa against aluminium hydrochloride induced neurotoxicity in male Wister rats. Int J Pharm Pharm Sci 2017;9:216-21.

25. Ohkawa H, Ohishi N, Yagi K. Assay for lipid peroxides in animal tissues by thiobarbituric acid reaction. Anal Biochem 1979;95:351-8.

26. Sumithra M, Arunachalam G, Chitra V, Gowri K. Neuroprotective effect of Sargassum ilicifolium Turner Carl Agardh on acetylcholinesterase activity and attenuation of scopolamine-induced amnesia in rodents. Asian J Pharm Clin Res 2016;9:93-6.

27. Li J, Wuliji O, Li W, Jiang ZG, Ghanbari HA Oxidative stress and neurodegenerative disorders. Int J Mol Sci 2013;14:24438-75.

28. Mushtaq N, Schmatz R, Pereira LB, Ahmad M, Stefanello N, Vieira JM, et al. Rosmarinic acid prevents lipid peroxidation and increase in acetylcholinesterase activity in brain of streptozotocin-induced diabetic rats. Cell Biochem Funct 2014;32:287-93.

29. Garcia YJ, Rodríguez-Malaver AJ, Peñaloza N. Lipid peroxidation measurement by thiobarbituric acid assay in rat cerebellar slices. J Neurosci Methods 2005;144:127-35.

30. Singh B, Pandey S, Verma R, Ansari JA, Mahdi AA. Comparative evaluation of extract of Bacopa monnieri and Mucuna pruriens as neuroprotectant in MPTP model of Parkinson's disease. Indian J Exp Biol 2016;54:758-66.

31. Rahman K. Studies on free radicals, antioxidants, and co-factors. Clin Interv Aging 2007;2:219-36.

32. Niidome T, Takahashi K, Goto Y, Goh S, Tanaka N, Kamei K, et al. Mulberry leaf extract prevents amyloid beta-peptide fibril formation and neurotoxicity. Neuroreport 2007;18:813-6.

33. Behl C, Davis JB, Lesley R, Schubert D. Hydrogen peroxide mediates amyloid beta protein toxicity. Cell 1994;77:817-27.

34. Whittemore ER, Loo DT, Watt JA, Cotman CW. A detailed analysis of hydrogen peroxide-induced cell death in primary neuronal culture. Neuroscience 1995;67:921-32.

35. Baylock RL. Excitotoxicity: A possible central mechanism in fluoride neurotoxicity. Flouride 2007;37:301-14.

36. Barad M, Bourtchouladze R, Winder DG, Golan H, Kandel E. Rolipram, a type IV-specific phosphodiesterase inhibitor, facilitates the establishment of long-lasting long-term potentiation and improves memory. Proc Natl Acad Sci U S A 1998;95:15020-5.

37. Nade VS, Kawale LA. Targetting serotonergic pathway for anti-amnesic activity by Morus alba L. Int J Pharm Sci Drug Res 2015;7:27-32. 